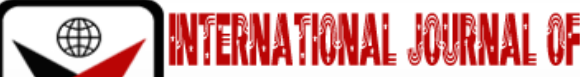

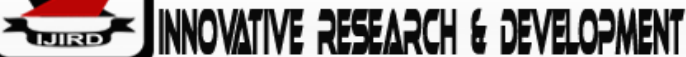

ISSN $2278-0211$ (Online)

\section{Enhancing Extractive Resource Governance in Ghana and Nigeria under Fragmented Policy Landscape and Limited Resource Scenarios: Insight from the Barrow Framework}

Kwaku Onwona-Hwesofour Asante
Executive Director, Department of Food and Environmental Sustainability Systems,
Agency for Health and Food Security, Ghana
Simon Abugri
Professor, Department of Forest Science,
University of Energy and Natural Resources, Ghana
Nana Sarfo Agyemang Derkyi
Professor, Department of Energy and Environmental Engineering,
University of Energy and Natural Resources, Ghana
Daniel Sarfo Akoto
Modular Programmes Coordinator, Department of Forest Science,
University of Energy and Natural Resources, Ghana

\begin{abstract}
:
Policy coherence is key to ensuring that the wellbeing of society is achieved within an environment that guarantees sustainable production and consumption patterns. From a conceptual lens of the Barrow Framework, we examine governance lapses in extractive resource governance and explore mechanisms for integrating policy coherence, environmental sustainability and strengthening governance arrangements in Ghana and Nigeria. The Barrow Framework's Index Score (BAR-X) employs Multi-Criteria Decision-Making analysis in a focus group discussion and Policy Coherence Analysis to identify policy gaps and prioritize institutions, socioeconomic and environmental themes. Policy coherence analysis of Ghana and Nigeria from the BAR-X showed an overall performance of $34 \%$ and $30 \%$ respectively falling far below the minimum expected score of $80 \%$. We demonstrate that resource governance policies of Ghana and Nigeria do not adequately address the tripod of institutional efforts, developmental load and the biospherical pivot. Under extremely limited resource conditions, it is recommended that civil society/non-profit organisations, financial institutions and regional institutions are supported with proceeds from extractive resources to particularly promote agroecology, technology and innovation towards maintaining ecological balance through preservation, protection, conservation and the reduction of ecological and carbon footprints.
\end{abstract}

Keywords: Extractive industry, environmental sustainability, natural resources, multi-criteria decision-making, sustainable development, policy coherence analysis

\section{Introduction}

Extractive resources, particularly minerals, soil and timber, have historically supplied the infrastructural, technological, energy and many other goods and services consumers enjoy. However, the global value chains for these high-valued commodities have been criticized as being abusive of economic, sociocultural and environmental rights of resource-rich communities and nations. Paradoxically, it has been found that countries with abundant natural resources such as gold, oil, bauxite, etc. tend to have less economic growth, poor democracy, and worse development outcomes than countries with fewer natural resources due to poor governance, limited accountability, poor transparency and weak technical capacity (Adams et al., 2018). The questions that development practitioners and scholars often ask has been how Africa's natural resources can be effectively governed to best serve the wellbeing and needs of Africans including staying within ecological limits and improving environmental quality. To this end the concepts of natural resource governance, sustainable mining and ecological governance among others are gaining popularity in discourses within the environment and natural resource space as activists and scholars question the role of extractive resources on human wellbeing and environmental sustainability. Questions such as what should inform mineral resource governance policy to guarantee sustainability?, how can existing policies be improved to facilitate the entrenchment and achievement of intergenerational equity for resource-rich countries?, what variables, themes and concepts should be prioritized or managed to achieve a balance between human wellbeing and environmental sustainability?, what role 
should institutions play in ensuring that natural resources serve the wellbeing and needs of society as well as guarantee ecological sustainability? continue to receive attention of researchers and development agents.

Giving Ghana's and Nigeria's mineral endowments and significant contribution to global mineral supply chain, (Africa Union, 2009) plus the abundance of many natural resources in Africa, the need for effective resource governance within the continent cannot be overemphasized. While the ontology on mineral and extractive resource governance in Africa is filled with arguments for and against foreign direct investments and public sector investment or management, the epistemology of achieving sustainability by the operationalization of wellbeing and ecological footprint has not been adequately articulated.

In its 2020 report, the World Bank (2020) estimates that the cost of environmental degradation (CoED) to the Ghanaian society is estimated at about US $\$ 6.3$ billion which is equivalent to 10.7 percent of the country's 2017 GDP. Similarly, Nigeria's CoED is also estimated at US\$9.7 billion (Croitoru et al., 2020). Air pollution, water pollution, gold mines, unmanaged solid waste, site contamination, agricultural land degradation, deforestation and overfishing are culpable for these estimates.

The need for policy coherence in extractive resource governance permeates the entire concept of the Sustainable Development Goals (SDGs), which are based on the idea that the multiple facets of development do not occur in isolation, but are impacted upon by many actors and policies (Schoeberlein, 2020). Successful implementation therefore relies heavily on governments taking an integrated approach to policy-making, with policy coherence driving activities around the SDGs and African Union Agenda 2063. SDG 17.14 particularly highlights the need to track policy coherence systemically (Schoeberlein, 2020).

The focus of the policy coherence component of this study on Ghana's and Nigeria's extractive resources is due to their long extractive industry experience and the fact that most of the key transnational corporations (TNCs) are operating on the continent. There are many examples and studies of Africa's artisanal and small-scale mining activities by companies and individuals. Civil society organisations have also expressed a strong voice in right-based advocacy.

Various scholars in development and resource governance have, thus, theorized a variety of frameworks, approaches and models to facilitate research, strategic planning, policy formulation, advocacy, change communication and project implementation. In an attempt to deal with the social, economic or environmental aspect of sustainability in extractive industry, poor policy coherence and institutional prioritization have been found. Popular among these approaches are the Sen's Capability Approach, Institutional Analysis Framework (Heikkila and Andersson, 2018) and quite recently, Kate Raworth's Doughnut Economics Model (Krauss, 2018). Recognizing the role of each of these frameworks in enhancing the ideological framings on sustainability, a new model that integrates these frameworks to help answer questions of how policies can change or be amended to facilitate sustainability governance of extractive resources in the African context is considered following a desk review and focus group discussion of policy frameworks around extractive resource governance.

The objective of this study is to examine how decisions and policies on mineral resources can be improved using insights from the Barrow Framework. The paper is organized into sections and subsection to facilitate the achievement of the objective. Methodology section captures preparatory activities and desk study, multi-criteria decision-making analysis, policy coherence analysis and the development of the Barrow Index. The results and discussion section highlights conceptual considerations, policy gaps and opportunities in mineral resource governance in Africa, opportunities for ecological transformation, bridging policy gaps from the lens of the Barrow Framework and a detailed policy coherence analysis that focuses on political commitment, policy integration, long term perspective, policy effects, policy coordination, local involvement, stakeholder engagement, monitoring and reporting, institutional arrangements and biospherical commitment. The study culminates into prioritization of institutions, development themes and environmental objectives under limited resource scenarios using multi-criteria decision-making analysis.

It is anticipated that progress in the governance arrangements for extractive resources achieved would diffuse across the African continent and beyond to influence policy developments in the extractive industry and the natural resource governance sector as a whole. The intended impact of this study transcends beyond the mining industry to include governance policies, resolving complex decisions, developing research, monitoring and evaluation framework for resource-rich communities, extractive industry policy reforms, sustainability governance among other applications.

\section{Methodology}

\subsection{Preparatory Activities and Desk Study}

The authors agreed on milestones as well as quality assurance procedures or measures after initial discussions. Extensive desk study and stakeholder consultations were done focusing mainly on gathering relevant literature and information on the review assignment. Relevant information on the extractive resource governance were sought from the internet, civil society organisations in the extractive sector, Mineral Development Commission and the Ministry of Lands and Natural Resources for critical scrutiny. The desk review concentrated on a comparative study of existing mining and mineral resource policy frameworks at the regional and national levels. Further, specific policies targeting Africa's mineral resource governance was reviewed, gaps identified and recommendations made for policy amendment.

Based on the research questions, a framework was developed to help explore how policies on mineral resources can be improved to take care of the human security and wellbeing needs of communities of resource-rich economies. A policy coherence framework was considered to reconcile the ecological functioning of the environment, institutional role and the mandate to promote development. Hence, key deliverable from this review in line with the work of Alozie (2019) 
include gap identification of existing mining and mineral resource governance framework, acquisition of feedback from key stakeholders and presentation of policy recommendations.

The steps followed in the review include preliminary theoretical reviews, preparatory activities, framework development, analysis of relevant literature, identification of gaps in existing policies, developing a scorecard for Ghana and Nigeria, prioritizing institutions, development goals and environmental themes and presentation of recommendations.

\subsection{Multi-Criteria Decision-Making Analysis}

We further developed an index BAR-X (Barrow Index) to help policymakers and stakeholders prioritize institutions, developmental objectives and biospherical themes using TOPSIS method of conducting Multi-Criteria Decision-Making (MCDM) Analysis (Hashemi et al., 2020). MCDM analysis was conducted participatorily with 30 stakeholders from public sector and civil society organisations in environmental governance. The following relations were used in a 6-step prioritization process.

Step 1: The normalized decision matrix was calculated using the normalized value $r_{i j}$ as follows:

$r_{i j}=x_{i j} \sqrt{\sum_{i-1}^{m} x_{i j}^{2}} \mathrm{i}=1,2, \ldots, \mathrm{m}$ and $\mathrm{j}=1,2, \ldots, \mathrm{n}$.

Step 2: The weighted normalized decision matrix was calculated from the weighted normalized value $v_{i j}$ determined as follows:

$$
v_{i j}=r_{i j} \times w_{j} \mathrm{i}=1,2, \ldots, \mathrm{m} \text { and } \mathrm{j}=1,2, \ldots, \mathrm{n} .
$$

where $w_{j}$ is the weight of the $j^{\text {th }}$ criterion or attribute and $\sum_{j=1}^{n} w_{j}=1$.

Step 3: The ideal best $\left(A^{*}\right)$ and ideal worst $\left(A^{-}\right)$values were determined.

$$
\begin{aligned}
& A^{*}=\left\{\left(\max _{i} v_{i j} \mid j \in C_{b}\right),\left(\min _{i} v_{i j} \mid j \in C_{c}\right)\right\}=\left\{v_{j}^{*} \mid j=1,2, \ldots, m\right\} \\
& A^{-}=\left\{\left(\min _{i} v_{i j} \mid j \in C_{b}\right),\left(\max _{i} v_{i j} \mid j \in C_{c}\right)\right\}=\left\{v_{j}^{-} \mid j=1,2, \ldots, m\right\}
\end{aligned}
$$

Step 4: The separation measures using the m-dimensional Euclidean distance were determined. The separation measures of each alternative from the ideal best value and the ideal worst value were determined respectively as follows:

$$
\begin{aligned}
& S_{i}^{*}=\sqrt{\sum_{j=1}^{m}\left(v_{i j}-v_{j}^{*}\right)^{2}, j=1,2, \ldots, m} \\
& S_{i}^{-}=\sqrt{\sum_{j=1}^{m}\left(v_{i j}-v_{j}^{-}\right)^{2}, j=1,2, \ldots, m}
\end{aligned}
$$

Step 5: The relative closeness to the ideal value was determined. The relative closeness of the alternative $A_{i}$ with respect to $A^{*}$ is defined as follows:

$$
R C_{i}^{*}=\frac{S_{i}^{-}}{S_{i}^{*}+S_{i}^{-}}, i=1,2, \ldots, m
$$

Step 6: The preference order was ranked.

\subsection{Policy Coherence Analysis}

We also addressed the gaps and track the progress of implementing policy coherence for natural resource governance and development. To construct BAR-X, we used ten sub-indicators consisting of an adaptation of eight subindicators of policy coherence developed by the Organisation of Economic Cooperation and Development (OECD) (Igrioglu et al., 2020). Two additional framework-derived sub-indicators were added to the eight sub-indicators as follows;

- Political commitment - Ensuring commitment to the developmental load and leadership at the highest level

- Policy integration - Maximizing synergies and minimize trade-offs between and among institutions, developmental imperative and environmental objectives

- Long-term perspective - Ensuring long-term plans that go beyond electoral cycles and seek balance with shortterm priorities

- Policy effects - Systematically considering the effects of policies on people's wellbeing and environmental performance

- Policy coordination - Assigning responsibility for coordination at appropriate level and establish clear mandates to resolve policy divergences

- Local involvement - Enabling participation of regions, cities, municipalities and communities 
- Stakeholder engagement - Engaging all relevant actors to identify challenges, set priorities, align actions and mobilise resources

- Monitoring \& Reporting - Using monitoring and reporting systems to adjust policies in light of potential negative effects

- Institutional Arrangements -Identifying the various institutions and defining their roles in ensuring wellbeing and environmental sustainability

- Ecological Commitment- Providing clear policy directives and establishing reward schemes towards ensuring that environmental degradation associated with resource exploitation are mitigated to guarantee the continued survival of biodiversity

\subsubsection{BAR-X Project Stages}

\subsubsection{Policy Analysis}

In order to assess the baseline and current situation of policy coherence for sustainable development (PCSD) implementation, we conducted an analysis of Ghana's and Nigeria's mining and mineral resource policies documents for the purpose of finding evidence on PCSD with respect to the themes presented in the Barrow concept (Fig. 1) and Framework (Fig. 2)

\subsection{Constructing the Index}

The Barrow Index on Resource Governance (BAR-X) is based on OECD's composite index that mixes eight subindicators. The proposed scale for policy coherence analysis are as follows:

0 - Not applicable - The building block is not applicable to the context where the assessment takes place

1 - The building block under assessment does not exist and there are no plans or actions for putting it in place

2- Building block under development - The building block does not exist yet, it is under development

3 - In place, not implemented - The building block is in place, but it is not implemented. (e.g., statements of commitment, but no action)

4 - In place, partly implemented - The building block is in place, but the level of implementation is not complete

5- In place, functioning - The building block under assessment is complete and relevant

Similarly, for cost-benefit and multi-criteria decision making, the following scale is used.

0 - Non-Existent

1- Low

2- Moderate

3- High

4- Very high

5- Extremely High (for cost) or Perfect (for benefit)

\section{Results and Discussions}

\subsection{Conceptual Considerations}

Historically, pre-industrial optimism of resource abundance and technological advancement resulted in the industrial revolution and fear of exhaustion of raw materials from population explosion. These events gave way to Malthusian population pessimism (Fischer, 2019), Boserupean agricultural intensification (Willy et al., 2019) theories, and the Brundtland's Commission Report of 1987 (World Commission On Environment and Development, 1987) which drew attention to the need for intergenerational equity in resource consumption. To date, theories, concepts, and policies underpinning sustainability and resource governance continue to undergo definitional transformations. For example, the acceptance of modernization theory by most of Africa and developing economies gave room for the development of Western viewpoint among Southern economies and seeing the west as the ideal for developing states. Ideologies of free enterprise and market economies emerged so that societies wishing to develop are obliged to open their markets, pursue export-oriented activities, adopt new and advanced technologies, withdraw state aid and privatize local economies. This way, the theory posits, poverty in the 'periphery' could be reduced by giving the 'core' more access to the periphery's resources and markets (Ahiakpor, 1985). Ironically, after years of following the modernization theory, poverty, inequality, and unemployment are still prevalent in resource-rich economies in Africa. Minerals, timber and oil resources have left the shores of Africa without a commensurate level of benefit for the resource-rich economies (Ojakorotu, 2019). The natural resources of Africa provide a unique opportunity to ensure human and economic development. However, Africa suffers from the paradox of plenty, for which abundant endowments of natural resources do not lead to equivalent levels of prosperity, broad-based development, and resource-based industrialization. One key obstacle preventing African countries from realizing this potential is poor governance. It is, hence, arguable that in spite of the contribution of modernization to the realization of human capacity and potential for some growth, benefits have largely been skewed to the North against the South.

While the dependency theory logically flows from the modernization theory by seeking to cut all ties and relations with the West, it is practically impossible and inappropriate in a globalizing world (Ahiakpor, 1985). Countries of the South owe it a duty to create or amend if need be, polices which would inure to the wellbeing needs of developing economies. 
In an attempt to influence resource governance policies, a number of scholars have theorized a variety of approaches. For example, Amartya Sen's Capability Approach (CA) draws on the results of fieldwork which critiques opulence and utility approach and concludes that neither of these approaches has an informational base broad enough to represent all aspects of human development. While the former is concerned with the material basis of wellbeing the latter is preoccupied with mental states. Clark (2005) argues that both these approaches can provide fairly misleading guides to wellbeing and that the CA is able to avoid these pitfalls by concerning itself with the ability to live well across all spheres of life and this includes accommodating material and mental aspects of development in addition to many other substantive freedoms, which are not directly covered by opulence- or utility-inspired frameworks. According to Anand (2013), for Sen, the value of the environment is not dependent on what it contains but on what it offers by way of opportunities to people. Sen further argues that while some human actions have negative impacts on the environment, there are also actions which improve the environment and therefore, the need to consider the 'constructive agency' of those who undertake actions to improve the environment. In spite of the contribution of the CA in human development and wellbeing, the CA is not a dynamic concept as presented also by Ballet et al. (2011); it is also very difficult to link the CA with the systemic level of sustainability analysis. For example, since the CA does not differentiate between stocks and flows coupled with the fact that the CA's higher complexity, multidimensionality, and the need for contextualization lead to an unclear understanding of decision processes (Rauschmayer and Leßmann, 2011).

Another influential framework in the resource governance and development space is the institutional analysis framework (IAD) developed by Elinor Ostrom. This framework relates to a set of concepts to help in the analysis of commons, mostly stock resources exploring which institutional structures support arrangements that handle resource stocks sustainably, balancing individuals' use with the interest of a wider public (Heikkila and Andersson, 2018). In a work on "governing the commons" Ostrom gives attention to governance and management of common-pool resources (CPRs), institutions dealing with such resources and their inner structure in an attempt to criticize the conventional policy analysis schemes. Consequently, efforts to govern CPRs were presented with the aim to develop a theory for a better understanding of capabilities and limitations of self-governing institutions (Ostrom, 2009). In spite of the enormous contribution towards laying the foundation for institutional governance for CPRs, the potential of CPRs in providing for the wellbeing needs and the mechanisms by which such development outcomes can be achieved are not adequately articulated. Institutional efforts are also limited to the coercive force of the state and the entrepreneurial efforts of firms in the private sector. The role of traditional authority, civil society, religious institutions, multinational corporations among others did not receive much attention. Additionally, the mechanisms for ensuring the continual ecological productivity of CPRs beyond generational exploitation are insufficient (McGinnis, 2011).

\subsection{Mineral Resource Governance in Africa, Policy Gaps and Opportunities}

In spite of the enormous investment in Africa's mining sector, there has been a plethora of criticisms that the sector is not contributing enough to the continent's economy, environmental sustainability and sociocultural outcomes because of over-dependence by the state on fiscal benefits without conscious effort to develop and coordinate formal and informal institutions, policies and ecological indices. According to (Barreto et al., 2018), the past decade has seen discourses around the participation of foreigners in small scale mining and their environmental impacts have dominated the public media and literature space. More worrying is the failure of state efforts at curbing the degradation associated with both local and foreigners-mediated illegal mining.

The policy environment around traditional and state governance of mineral resources in Ghana, for instance, are conflictual in nature- while Ghana's mineral and mining policy posits that small-scale mining is reserved for Ghanaians and that all minerals belong to the state, traditional authority sees themselves as the original owners of the lands and mineral resources prior to Ghana's independence and constitutional rule. Hence, local chiefs and family heads are able to lease lands for mining under the guise of development to both locals and foreigners while those lands are degraded under illegal mining activities. Also, conflict of interests among politicians and law enforcement agencies and lack of skill among the youth in rural areas continue to drive the interest in illegal and small-scale mining (Boafo et al., 2019). Consequently, environmental restoration, reclamation or remediation requirements accompanying the degradation are avoided culminating in the prevalence of open pits, chemical pollution of water resources and unproductive topsoils for local farming across mining areas.

To address the mineral resource governance challenges, the African Mining Vision and Action Plan was developed under the auspices of the Africa Union to use Africa's mineral resources to reduce the continent's poverty and accelerate its social and economic development through industrialization; based on its natural capital and enable the continent to excel in the global economy (Ambe-Uva, 2017). On the sub-regional level, the ECOWAS Mineral Development Policy and the ECOWAS Directive on the harmonization of guiding principles and policies in the mining sector have been developed. One of the key objectives of these ECOWAS initiatives are to provide a mining environment that is responsive to sustainable development and balances the need to provide the appropriate incentives to attract investors with the protection of the revenue base and resources of member states (Twerefou, 2009).

The Africa Mining Vision and Action Plan, while seeking to develop policies in line with international conventions, regional and sub-regional policy frameworks, does not adequately cater for the wellbeing needs of the present and future generations in line with the outcome of the Rio+20 Summit which emphasizes a development approach involving wise use of natural resources, respect for the environment and equitable distribution of resources (Zilberman et al., 2019). Although the policy highlighted green economy in the context of sustainable development and poverty eradication as one of the important tools for achieving sustainable development and maintaining the healthy functioning of the Earth's ecosystems, the institutional arrangements, wellbeing indicators, and ecological factors considered are not robust enough 
to guarantee intergenerational equity and sustainability. Addressing these challenges will position Africa's extractive industry to becoming internationally competitive, whilst at the same time ensuring that the expected benefits due the state, communities and investors are realized (Li et al., 2019).

\subsection{Opportunity for Ecological Transformation}

From various principles tagged with sustainability leading to the Millennium Development Goals (MDGs) and to the Sustainable Development Goals (SDGs) the concept of environmental sustainability has been crosscutting. Globally, more than 100 million people depend directly or indirectly on artisanal mining for their livelihoods. In Ghana, for instance, Wilson et al., (2015) estimated 1.1 million people directly work in Artisanal and Small Scale Gold Mining (ASGM) activities, representing nearly two-thirds of the country's total mining labor force. For mining to become sustainable within the environmental context, the governance arrangements for institutions, developmental goals and ecological footprints including management of the top and subsoil stockpiled for re-vegetation activities must be of the sort that guarantees comparable quality to those of undisturbed or pre-disturbance. However, the policy landscape around environmental governance emphasizes only on above-ground biodiversity to the neglect of soil productivity (Suryawan \& Aris, 2020). Stockpiles often used for reclamation activities do not meet the necessary ecological conditions for sustainable soil productivity. This is attributable to the fact that most stockpiles are overaged extending from a year to a century and over, apparently because reclamation and use of the stockpile is dependent on mine closure plan and period which can be very extensive.

There is also poor policy and regulatory mechanisms for mine reclamation and stockpile management (Mensah et al., 2015). As a result of the extended age of stockpiles with their high depth (beyond $6 \mathrm{~m}$ ), the use of heavy equipment in the stockpiling process and the resultant nutrient volatilization, leaching, mineral compaction and sedimentation, there is a concomitant degradation of soil physicochemical properties including aeration, cation exchange capacity, gravimetric moisture content, soil carbon, nitrogen and phosphates among others. Again, the loss of vegetational biomass associated with the stockpiling process truncates the soil carbon cycle leading to loss of soil flora and fauna and soil biodiversity in general (Kuan et al., 2020).

Even for most small-scale and illegal mining operations, reclamation and restoration activities are not a priority. Hence, topsoils are washed without any attempt at remedying the site under exploration and exploitation. Worse is the use of hazardous chemicals which pollute soils and end up in water resources to the detriment of humans and aquatic organisms. At the community level, people feel alienated and excluded from the benefits of indigenous natural resources. Sometimes, bitterness, alienation, and exclusion breed conflicts between communities and mining companies. The need for a coherent comprehensive governance framework for mineral resources is therefore paramount.

\subsection{Bridging Policy Gaps with the Barrow Framework}

\subsubsection{Conceptual Framework}

A wheelbarrow is a small hand-propelled vehicle, usually with just one wheel, designed to be pushed and guided by a single person using two handles at the rear. In scientific literature, the wheelbarrow (Fig. 1) is classified among simple machines as a second-class lever, because the load is between the effort and the fulcrum or pivot. Apart from its application as a simple machine, the design could also serve as a useful tool in policy analysis, review and recommendations where the effort represents the role of institutions in the business of sustainability and development, the load portrays the objectives, themes, outputs and outcomes of development policies and frameworks and the fulcrum presents the pivotal role and impact of healthy ecosystems and the protected biosphere on the provision of continued support to both institutional efforts and developmental load. The bars linking the three parts represent the interactions between and among institutions, developmental outcomes and the biosphere. These interactions are the cross-cutting issues of policy coherence, gender, legal framework, partnerships, and benefit-sharing.

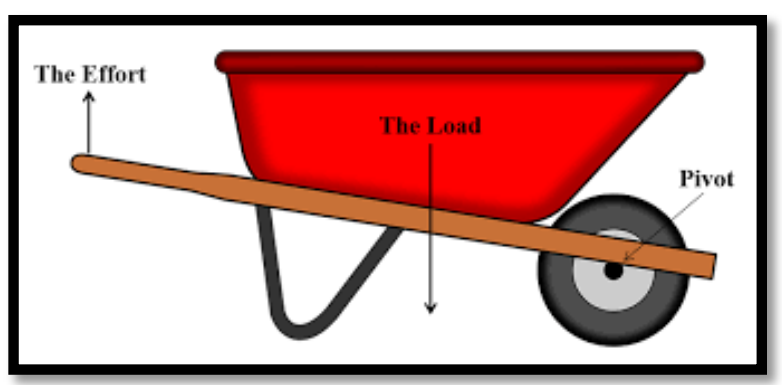

Figure 1: The Wheelbarrow Concept

\subsubsection{Institutional Effort}

The institutional effort of the Barrow Framework (Fig. 2) denotes the various actions by public, private, formal, informal, local and transnational actors in creating, coordinating, enforcing, implementing, monitoring and evaluating projects, programs, policies, and laws to promote multigenerational stewardship of natural resources and to guarantee wellbeing and sustained ecological productivity of indigenous communities and resource-rich nations through the proceeds from the resources being exploited. 


\subsubsection{Relevant Institutions in Resource Governance}

For effective resource governance, institutional mapping, analysis, and engagements are paramount (Henckens et al., 2019). Within the African context, national and decentralized public agencies, private enterprises sector, civil society organisations, traditional authority, religious groups, informal groups, community leaders, regional cooperation and integration agencies, financial institutions and other external influencers play a significant role in ensuring whether or not the mineral resources and other natural resources in Africa are directed at the human security, wellbeing needs and ecological functionality. While the actors vary in the type and scale of influence, none of them is of least importance. For example, natural resource-associated public sector ministries and agencies might concern themselves with developing and enforcing governance policies but the role of civil society organisations and religious institutions in driving the culture of stewardship and intergenerational principles of equity and sustainability cannot be overemphasized. Similarly, reorientation of the private sector on ecological productivity and societal wellbeing to inform improved corporate social responsibility and philanthropy is critical. Partnership with traditional authority in the creation, enforcement and benefitsharing policies of resources with the state and decentralized agencies are crucial to resolving the age-long conflicts between the state and traditional authority on resource governance. Special incentive packages and reward systems need to be created for traditional leaders and individuals whose lands have been identified as resource-endowed. This way, adherence to conservation and sustainable mining policies can be guaranteed (Boafo et al., 2019).

Again, for the purposes of participation and collective responsibility, informal groups who share common experiences, skills, interests and aspirations in the sustainability of natural resources can be mobilized, trained and resourced to champion restoration, reclamation or remediation of degraded ecosystems through bankable green economic projects that guarantee mass employment, ecosystem functioning and overall wellbeing as highlighted in Fig 2.

While many appreciate the enormity and complexity of global environmental problems, the actual degradation or remediation happens at the local community level. As the concept of thinking globally and acting locally gain preeminence (Alozie, 2019), the role of community leaders ought to be clearly delineated in policy deliberations to transform anthropocentric local behaviours from degradation and exploitation to biodiversity restoration, benefit-sharing, and the advancement of societal wellbeing.

Regional cooperation and integration agencies can be instrumental not only in developing overarching resource governance policies for the benefit of member countries (Schoeberlein, 2020) but to also monitor the localization of policies across countries, support transformative research, develop databases and wellbeing scorecards for countries with reward systems for top transformers and empower national institutions with the capacity to transform natural resources into high-valued finished products with better price and market mechanisms for the benefit of Africans or owners of the resources under consideration. In view of this, focal persons in the African Union, United Nations, among other institutions in the extractive industry must be acknowledged, consulted and engaged to inform policy analysis, stakeholder mapping and engagements, capacity building and technology transfer (Sarkodie, 2020).

To accelerate the achievement of regional and global development goals such as the AU Agenda 2063 and UN Agenda 2030 in relation to ensuring both natural and man-made capital, address the wellbeing needs of present and future generations, the inclusion of financial institutions which assume the risk of companies and plants can be of considerable influence. According to Adewuyi and Olubiyi, (2020) this is achievable by the financial institutions exercising control over investment and management decisions which could be brought into play for the benefit of the environment.

Practically, financial institutions in acting as investors, interact positively with the environment by supplying the investment needed to achieve human security and social wellbeing. They also act as innovators to develop new financial products that promote wellbeing and environmental sustainability (Adams et al., 2018). Negative interactions could also emanate from financial institutions to include their role as consumers of pollution-generated resources and as victims of environmental change such as climate change. Thus, the financial markets present a myriad of opportunities for environmental policy. While some actors suggest that environmental performance does not contribute to good financial performance, it must be noted that a good evaluation framework like the Barrow Framework (Fig 2) demonstrates clearly the fallacy of such assertions by considering the long-term productivity of the biospherical pivot which can guarantee sustained economic returns in the long-run compared to degradative tendencies of a myriad of natural resource projects which do not have any recovery or remediation plans but, however, produce unsustainably high returns in the short-run (Pislaru et al., 2019). Although not a mandatory institutional inclusion requirement, the involvement of external influencers who have long-term experiential knowledge over the political, economic, social, technological, environmental, and competitive factors with high social following in the governance and management of natural resources can be enriching.

\subsubsection{Developmental Load}

Developmental Load (DL) of the Barrow Framework (Fig 2) entails the various gaps, challenges, mandates and obligations that public, private, formal and informal institutions can contribute to the delivery of essential services to citizens and communities through the development of new industries and infrastructure, ensuring human security and wellbeing of the populace and promoting sustainable development. This section of the Barrow Framework examines the critical roles, challenges and improvements that institutions owe to their communities and nations, and are mandated to provide.

According to Mutize and Tefera (2020), a well-governed, efficient and profitable institution that delivers on their developmental mandates are crucial for African countries to achieve inclusive economic development, promote wellbeing 
and support ecosystems by expanding the technological and infrastructural base and facilitating natural and man-made capital development.

In many developing and developed economies, a considerable number of institutions have, in spite of good intentions, generally been less efficient (Adewuyi \& Olubiyi, 2020). Particularly in post-colonial Africa, many institutions struggle to reach many of their key developmental mandates. Notably, poor policy landscape and implementation, lack of skills transfer, inability to generate new technology and to create new industries which were previously not present or underdeveloped are culpable for much of Africa's underdevelopment (Giurco et al., 2009). Institutions have often failed to play the catalytic role in ensuring social wellbeing and improved environmental management. They have struggled to scale up Africa's extensive informal and traditional sectors, and often excluded religious and civil society organisations in the creation of policies for the natural resource sector. As argued by Boafo et al. (2019), it is worthy to state that institutions have not adequately contributed to boosting social wellbeing and environmental sustainability with poor economic growth, infrastructure development, poverty reduction and inequality reduction efforts seen so far.

With the adoption of the SDGs and AU Agenda 2063, institutions have a critical role in creating the enabling environment for and accelerating the achievement of these development agenda (Adewuyi and Olubiyi, 2020). Notable themes under which institutions are mandated to channel the proceeds of mineral resources and all other natural endowments include green economic ventures such as agriculture and forestry development; light power and industry; skill and talent development; science, technology and innovation including improving internet access and connectivity; promotion of human rights and freedoms including the right to health and clean environment; developing systems for ensuring effective participation and transparency in governance; promoting research and development across disciplines; providing public sector support to improve management effectiveness and efficiency; establishing systems to promote private sector development in the agribusiness, life science, green business and creative industry sectors; and supporting social protection development initiatives. It is important to note that other factors, themes and parameters may also be of relevance depending on the socioeconomic and cultural contexts of the resource-endowed community or state (Fig. 2).

In order to accelerate the achievement of the SDGs and AU Agenda 2063, African governments have a special mandate to clearly determine how various developmental and environmental objectives should be balanced, evaluated and prioritised. Bradly and Nathan, (2019) assert that African institutions must be compelled to provide a reasonable return on investment particularly those of public and private sectors, which include financial and social objects, deliver the public goods efficiently and manage such organisations accountably. According to Ngan et al. (2019), African institutions in the development sector should move to a system of using the values of human security, social wellbeing and environmental sustainability as the key performance indicators for their institutions. Parliaments must improve their mandates to hold development institutions accountable (Dawson and Maricut-Akbik, 2020). In South Africa, amendments to the Public Audit Act gave the Auditor General more power to ensure accountability in the public sector, including institutions. The amendments provided the Auditor-General with the power to refer material irregularities to appropriate authorities to investigate as well as the power to recover money lost as a result of such irregularities. In Ghana a similar arrangement is in place but political interference does not render the effective delivery by the office in exercising its mandate at curbing corruption (Zilberman et al., 2019). When political interferences are restricted, this mechanism could be something many other African economies can benefit from.

\subsubsection{Biospherical Pivot}

Biospherical pivot in the Barrow Framework (Fig. 2) refers to the fundamental role of ecosystems in their combined physical and biological contribution to sustaining developmental and institutional mandates and providing for the wellbeing needs of society with the understanding that living organisms in their ecosystems form complex sets of relationships and function as a unit as they interact with their physical environment to sustain the life of man and other organisms and maintain the integrity of the physical environment. The biospherical pivot also entails ecosystem services that people obtain to entrench human security and wellbeing needs including the provisioning, regulating and cultural services that directly affect people and supporting services needed to maintain the other services. This includes the availability of adequate food and water, to disease regulation of vectors, pests, and pathogens, human health and wellbeing underpinned by resilient biodiversity.

The causal links between environmental change arising from extractive industry or other exploitative activities and human wellbeing are complex because of their indirect nature. Human health and wellbeing ultimately depend upon the availability of freshwater, food and fuel sources from ecosystem products and services which are requisite for productive livelihoods and sustained biodiversity (Melo et al., 2020). Significant negative impacts can occur if ecosystem services are no longer adequate to meet social and ecological needs. Indirectly, resource extraction-induced changes in ecosystem services affect livelihoods, income, local migration and drive conflict. The resultant impacts on development, institutional sustainability and intergenerational equity can be catastrophic if not adequately managed.

It is in view of the above that a number of themes have been highlighted to guide assessments of the biospherical pivot of the Barrow Framework namely, physicochemical environment, species dynamics, ecological and carbon footprints, stockpile management, circular economy, environmental assessments, inter-ministerial and inter-sectoral coordination, preservation, protection and conservation, keeping within ecological boundaries and bioremediation.

Considerations of physicochemical environment in environmental governance policy evaluations are important to track the management of physicochemical changes such as bulk density, pH, cation exchange, exchangeable cations, exchangeable acidity, nitrates, phosphates, potassium, calcium, sulphates, heavy metals mobility among others arising from exploration and exploitation of natural resources. These parameters are critical to protecting ecosystems, ensuring species wellbeing and promoting intergenerational equity. Similarly, one of the major components of modern ecological 
assessments focuses on understanding what influences the abundance of organisms within a population, and why this abundance changes over time in species population dynamics. The assessments of these dynamics enable the estimation of carrying capacity of ecological resources needed to sustain the various species under consideration.

Individuals, events, organisations, services rendered and products of human origin generate varying amounts of greenhouse gas emissions as carbon footprint. Drawing from the natural capital, human activities also consume a considerable amount of nature and leave an ecological footprint over a long period of time. The activities of exploiting oil, timber, gold, bauxite, etc. leave significant ecological and carbon footprints which should not be allowed to go without mitigation arrangements stipulated in policies and regulations.

For mining in particular, stockpile management is key to ensuring ecological productivity (Kuan et al., 2020). This is because the layer which comes last informs the species population dynamics within the soil to inform the above-ground vegetation and biodiversity. In the process of stockpiling, when the topsoil is placed last, revegetation can be relatively faster than when the subsoil shows up. Again, amendments of the topsoil with cover crops, compost, biochar tend to increase the carbon stock and facilitate activities of soil micro and macro organisms (Mezeli et al., 2020). It is equally important that as part of environmental management during mine closure, measures are taken to close all pits and level the ground adequately for ecologically-friendly land use activities such as horticulture, silviculture, social forestry, aquaculture, permaculture, apiculture, animal husbandry and agronomic activities among others (Manero et al., 2020). To reduce the ecological footprint of extractive activities, the values of circular economy must be harnessed to encourage the reuse, sharing, rehabilitation, refurbishment, remanufacturing and recycling of environmental resources and to create a closed-loop system, minimizing the use of resource inputs and the creation of waste, pollution and carbon emissions. Environmental policies and practices must equally accommodate environmental assessments with a comprehensive arrangement for mitigating emissions and degradations.

Bearing in mind the complexity and multidimensionality of interrelationships among ecological factors (Bentham et al., 2020), sectors of development and ministries involved, a mechanism of coordination and ensuring policy coherence among actors on the use and recovery of resources in the provision of wellbeing needs of society and the prevention of degradation and emissions must be given serious attention. The option of preservation, protection and conservation should be prioritised for globally-significant biodiversity areas (GBSA) and ecosystems irrespective of the mineral deposits embedded in those ecosystems (Sor et al., 2020).

Understanding that the survival, growth and development of biodiversity are dependent on a limited volume of resources from abiotic components, deterioration of these limited resources can be catastrophic for the living systems. Policy must therefore limit and control the extent to which the abiotic factors of land, air and water resources are degraded in keeping within ecological boundaries (Dabachi et al., 2020). Under unavoidable circumstances where the growth media of land or water resources are degraded because of spillage, erosion, leaching or volatilization of nutrients, bioremediation could be given a priority with technologies such as phytoremediation, mycoremediation, bioventing, bioleaching, landfarming, bioreaction, composting, rhizofiltration and biostimulation. Environmental governance policies cannot afford to leave these parameters to chance. They must be planned for, assessed, monitored and effectively managed to provide for and guarantee intergenerational equity.

\subsubsection{Effort-Load-Pivot Interactions}

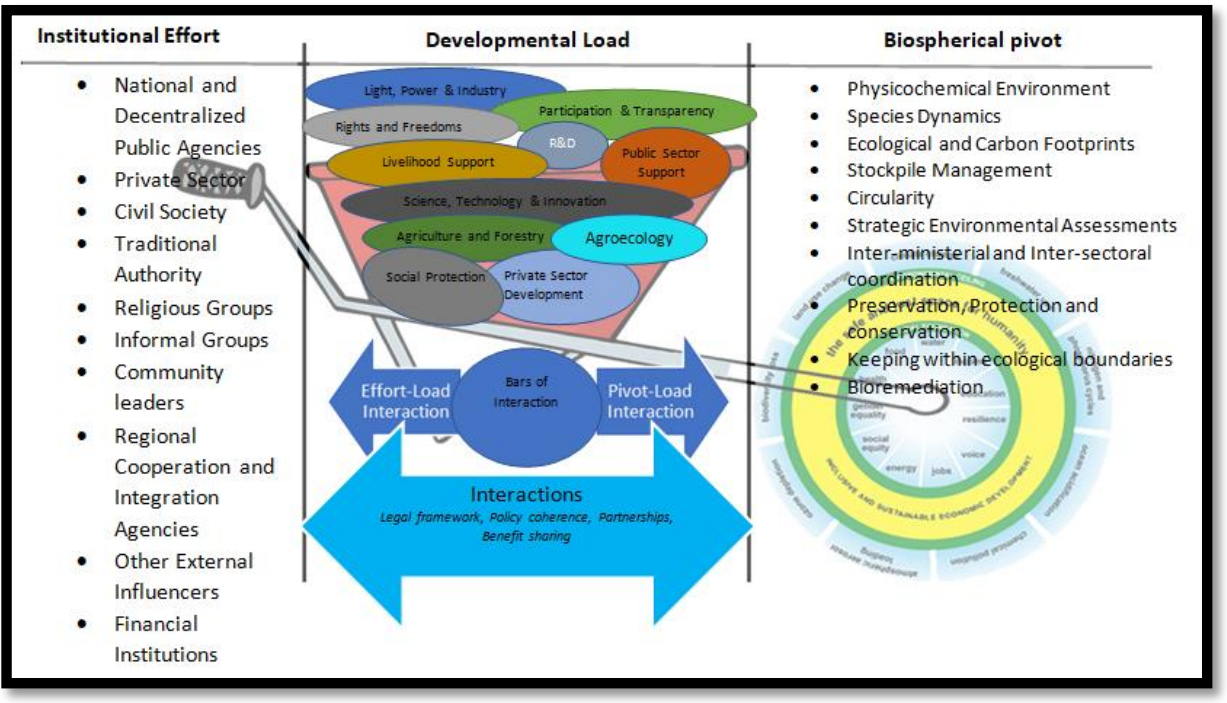

Figure 2: The Barrow Framework on Extractive Resource Governance for Sustainable Development Source: Author's Construct

\subsection{Policy Coherence Analysis}

Based on the 10 indices of the Barrow Framework, assessment of mineral and mining policy documents and historic research reports on mineral resources of Ghana and Nigeria were carried out. The areas of assessment were political commitment, policy integration, long term perspective, policy effects, policy coordination, local involvement, stakeholder engagements, monitoring and reporting, institutional arrangements, and biospherical commitment. 


\subsubsection{Political Commitment}

Ghana does better than Nigeria on the political commitment to using mineral resources for development although both countries fall far below the minimum acceptable score of 4 out of 5 (Fig. 3). Ghana's political commitment to ensuring national development with mineral resources is evidenced by the Mineral Income Investment Act 2018. However, the provisions in the act are not yet implemented and appear too general. The themes under the development load of the Barrow Framework are largely absent. For Nigeria, in spite of the fact that more than 80 percent of the budgets of some sub-national governments depend on resource revenue transfers from the central government (Bauer et al., 2016), there is no clear publicly available commitment to ensuring revenues from natural resources are directed to the developmental objectives presented in the Barrow Framework.

\subsubsection{Policy Integration}

Like political commitment, Ghana outperforms Nigeria in policy integration with a score of 2 and 1 respectively for Ghana and Nigeria out of a minimum acceptable score of 4 (Fig. 3). This is due to the fact that Ghana is making attempt to maximize synergies and minimize trade-offs between and among institutions, developmental imperatives and environmental objectives. For example, based on a number of research reports (Boafo et al., 2019; Fuso Nerini et al., 2019; Besada \& Martin, 2015) news publications and comments from Ghana's Ministry of Lands and Natural Resources, the Environmental Protection Agency, Ministry of Environment Science and Technologies, Forestry Commission among others, institutional coordination towards maximizing synergies and minimizing trade-offs for development and environmental sustainability remain weak. Similarly, in Nigeria there has not been much efforts in maximizing synergies and minimizing trade-offs between and among institutions, developmental imperatives and environmental values. Ango et al. (2019) argue that Nigeria's mining sector is dominated by illegal and informal miners and recommends formalization as a mechanism to minimizing tradeoffs and maximizing synergy among institutions.

\subsubsection{Long-Term Perspective}

Under long-term perspective, Ghana and Nigeria are at par with a score of 3 (Fig. 3) in ensuring long-term plants go beyond electoral cycles and seek balance with short-term priorities. However, while policy documents present indicators of long-term perspectives, implementation has not happened yet. It is noteworthy to state that Ghana's Mineral and Mining Policy and the Mineral Income Investment Act 2018 portrays a long-term perspective to development beyond electoral cycles. However, these policies do not adequately address ecosystem concerns in the biospherical pivot and institutional stakeholder involvement. For example, the Mineral and Mining Policy focuses on above-ground and aquatic biodiversity and neglect below-ground biodiversity of critical stockpiles, soil micro and macroorganisms and the Mineral Income Investment Act 2018 makes no mention of the use of any fraction of the proceeds from mineral resources for the mitigation of degradation accompanying extraction of minerals. These lapses have the tendency to create conditions for biodiversity losses, generate conflict and tension between miners and communities and shorten the mine life. Nigeria Mineral and Mining Act 2007 makes provision for long-term regulation of exploration and exploitation of minerals for development. However, majority of the provisions are yet to be implemented. This view is in tandem with those of Andrews \& Okpanachi (2020), Agelebe (2019) and Efobi et al. (2018).

\subsubsection{Policy Effects}

Based on the Mining and Mineral Resource policy and Mining Incomes Investment Act in Ghana, there is no systematic means of assessing the effect of the extractive industry policies on the wellbeing of Ghanaians and the environmental performance. The Environmental Protection Agency has been in charge of formal mining operations but informal and small-scale miners are left alone in their degradative activities in spite of failed efforts by the Ghanaian government to stop illegal mining activities in the country. Just like Ghana, Nigeria has not yet developed any systematic means of considering the effects of mining and natural resource policies on people's wellbeing and environmental performance. Hence, both countries attain a score of 1 out of 5 (Fig. 3) to signal that there have not been any systematic efforts to consider the effects of policies on people's wellbeing and environmental performance. Akana \& Ikegbunam (2019) and Adams et al. (2018) made similar observations.

\subsubsection{Policy Coordination}

Both Ghana and Nigeria obtain a score of 1 out of 5 on policy coordination following the fact that there are no plans presently to assign responsibility for coordination at national and sub-national levels and to establish clear mandates to resolve issues of policy divergence. To date, institutions within the extractive sector in Ghana remain fragmented over the definition of mandates, policy convergence and responsibility assignments. Political interference and corruption (Bauer et al., 2016) continue to keep institutions fragmented. Similarly, Nigeria has not benefited from any policy coordination arrangements. Barreto et al. (2018) argue that the limitation in policy coordination retards the ease of doing business in Nigeria to a value far less than $25 \%$.

\subsubsection{Local Involvement}

Under local involvement, both Ghana and Nigeria obtain a score of 2 out of 5 (Fig. 3). This is due to the fact that the building block of policy coordination does not exist yet, but under development. The UN Agenda 2030 has an overarching principle of leaving no one behind just like Ghana's Decentralization Policy. However, the involvement of stakeholders in national policy formulation particularly for the extractive industry sector is limited mainly to a few political actors in the capital city of Accra. Voices outside Accra are largely excluded. In revenue-sharing arrangements, traditional leaders and 
local governments at decentralized levels tend to feature local involvement on a smaller proportion. A report from the Natural Resource Governance Institute (2015) estimates that $90 \%$ of revenue from extractive industries is controlled by central government while the remaining $10 \%$ is shared among landowners, producing regions and producing municipalities. With about $80 \%$ of the Nigerian mining space in the unregulated informal sector, the country is yet to see formalization and structured involvement.

\subsubsection{Stakeholder Engagement}

Ghana and Nigeria obtain a score of 2 and 1 respectively out of 5 (Fig. 3). This is attributable to the fact that for Ghana the building block of stakeholder engagement is under development in ensuring that all relevant actors are adequately engaged to identify challenges, set priorities, align actions and mobilise resources to oversee effective implementation that connects institutions to development and environmental protection. The score of Nigeria is lower because there are presently no plans or actions in place to engender stakeholder engagement from the lens of the Barrow Framework.

The stakeholder space within the extractive sector in Ghana is not adequately utilized by Government over the years (Seck et al., 2020). The involvement of civil society, religious institutions, affected communities have often been an afterthought. For Nigeria, Aina (2018) describes the social and environmental policies as currently incoherent, haphazard and unregulated. According to Prpich et al. (2019), Nigerian environmental governance has been ineffective because of lack of adequately trained and experienced personnel to engage with, lack of expertise, and misaligned socio-economic expectations.

\subsubsection{Monitoring and Reporting}

Both Ghana and Nigeria are at par with a score of 1 out of 5 (Fig. 3) because there are presently no plans or action in place to use monitoring and reporting systems to adjust policies in mining and extractive industry in light of potential negative effects. States' Environmental Protection Agencies (EPA) is mandated to facilitate the demand, monitoring and reporting on environmental assessments such as Environmental Impact Assessments (EIA), Environmental Auditing (EA), Strategic Environmental Impact Assessments (SEIA) among other assessments. Apart from these arrangements, Ghana presently does not have any monitoring and reporting system in place to adjust policies to prevent or mitigate potential negative effects of anthropogenic activities on the environment at decentralized levels (Daum et al., 2020). Efforts of EPA have often been challenged by political patronage, the weak legal framework on environmental quality assurance, limited human resource, limited attention by civil society and media organisations on protecting the biosphere from pollution and degradation. While Nigeria's mineral resource monitoring and reporting mechanisms remain generally weak, Obiri \& Bjeirmi (2019) argue that the monitoring landscape of oil and gas sectors have seen improvements over time.

\subsubsection{Institutional Arrangements}

Ghana and Nigeria are at par with a score of 2 out of 5 (Fig. 3) on institutional arrangements towards identifying and defining the role of institutions in promoting wellbeing and environmental sustainability. The score is informed by the fact that the building block of institutional arrangements is still under development. Identification and engagement of institutions on investment direction of proceeds from natural resources in Ghana have been historically skewed towards public sector Ministries, Departments and Agencies and Multilateral Agencies. Engagement of CSOs, local-level actors at the community level, faith-based organisations (FBOs), financial institutions, regional entities and international entities on common approaches to protecting the biosphere, reinvestments, mitigation and restoration activities remain poor. Nigeria's institutional efforts towards ensuring social wellbeing and environmental sustainability are equally inadequate. Voices and actions of the private sector, civil society actors and religious institutions remain low. Alumona and Onwuanabile (2019) assert that both the federal and state environmental protection agencies (SEPAs) and their local government counterparts lack institutional capacity, equipment and adequate staff for effective implementation of environmental policies.

\subsubsection{Biospherical Commitment}

Under biospherical commitment, Nigeria does better than Ghana with a score of 2 against 1 out of an expected score of 5 (Fig. 3). Nigeria's score is attributable to the fact that a national commitment is still under development towards providing clear directives, rewarding and punishing environmental degradation. Ghana, however, does not have any plans or action in place to provide clear directives, reward compliance, punish degradation-associated with resource exploitation and mitigating the effects of anthropogenic activities on ecologically sensitive biodiversity areas. In their study, Idemudia et al. (2020) established that the Ghanaian government amendment to the original PNDC law 153 that governed mining via its repeal and replacement with ACT 703 of 2006 does not provide a clear and specific mechanism through which communities may formally seek redress for the violation of their environmental rights compounded with the fact that the 1992 Ghanaian constitution makes no direct reference to the environment and thereby creating ambiguities as the measures that are actually implemented often depend on both the administrative capacities of the agencies and the clarity of the policies and laws. For Nigeria, Meer et al., (2020) argue that a commitment to ecological sustainability is long entrenched in national policy and has been articulated extensively through the development of most of the Nigerian natural resource plans and legislation. However, to date these commitments have not succeeded in stopping the decline of biodiversity and degradation of environment in Nigeria. 


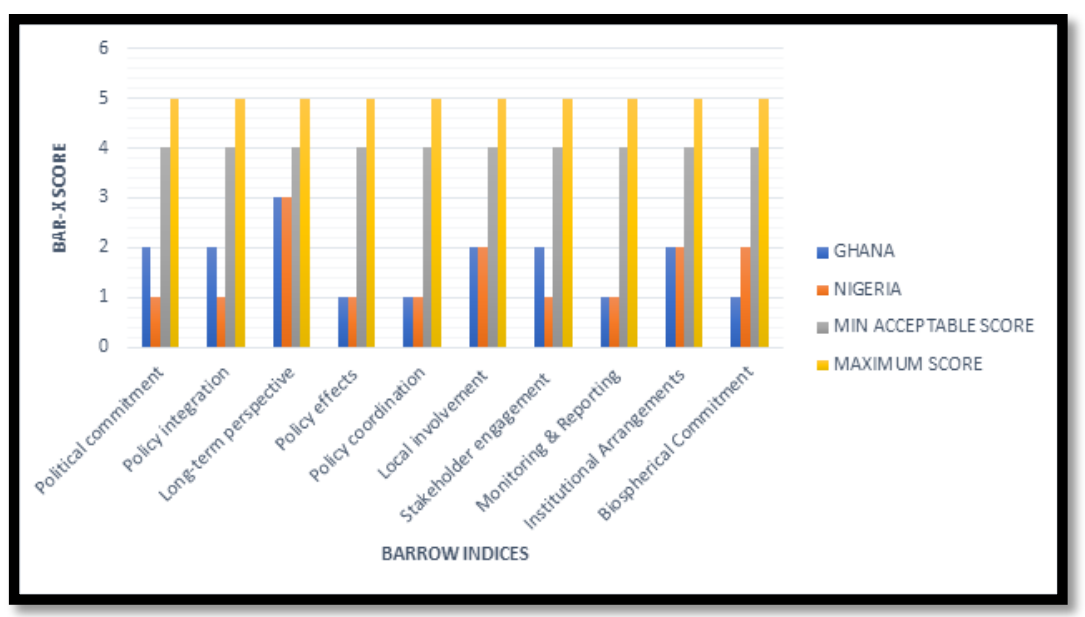

Figure 3: BAR-X Results for Ghana and Nigeria

From the above discussions, it is demonstrated that extractive resource governance in Ghana and Nigeria and to a large extent most of Africa have not performed satisfactorily on policy coherence and commitment to remedying environmental degradation. Suryawan and Aris (2020) argue that the constitutions of Ecuador, Bolivia, Switzerland, Egypt, and France explicitly support the environment, like water, mountains, sea, rivers, forests, animals; and as subjects of law and the State, corporation, and citizens are obliged to protect them. Although these countries have not been subjected to the Barrow Framework, they appear to offer some glimpse of assurance that they are committed to protecting the biosphere. The governance landscape for Africa in extractive resources would require a more thoughtful and consultative efforts to connect the efforts of institutions, wellbeing objectives and commitment to environmental protection.

After analyzing Ghana's and Nigeria's policy documents and research reports from the lens of the Barrow Framework, both countries (Fig. 3) fall far below the minimum threshold mark of $80 \%$ with a total score of $34 \%$ and $30 \%$ respectively. The low scores are attributable largely to the low coordination of institutions, limited prioritization for developmental objectives and poor commitment to protecting the biosphere.

\subsection{Multi-Criteria Decision-Making Analysis}

To help decision-makers prioritize based on limited resources, 30 managers of public sector, private and civil society organisations with mandates and understanding in sustainability were allowed to prioritize the themes presented in the Barrow Framework for maximum impact under resource-limiting scenarios after agreeing on individual BAR-X scores for decision alternatives. Figures 4, 5 and 6 presents the normalized decision radars for institutions, developmental objectives and environmental interest respectively. The radars show a generalized dilemmic scenario presented to policymakers under resource-limiting conditions. After following the MCDM process of weighting and determining the performance values of the individual decision alternatives a clearer output is obtained (Tables 1,2 and 3) that enables the ranking and subsequent prioritization of alternatives underpinned by least cost and maximum benefit. From the institutional prioritization matrix (Table 1), the order of prioritization in terms of which institution offers the least cost and maximum socioeconomic and environmental benefit is Civil Society > Financial Institutions > Regional Entities > Traditional Authority > Private Sector Entities $>$ Religious groups $>$ Public Sector Agencies.

Further, Table 2 presents the prioritization matrix for themes in developmental load to help decision makers decide on which development objective to pursue based on least cost and maximum derivable benefit. The prioritization order follows from Agroecology $>$ Science, Technology and Innovation $>$ Research and Development $>$ Forestry $>$ Participation and Transparency $>$ Human Rights and Freedoms $>$ Livelihood Support/Social Protection $>$ Mining $>$ Light, Power and Industry > Private Sector Development $>$ Conventional Agriculture.

Additionally, Table 3 provides a prioritization matrix for environmental themes and objectives with least cost and maximum socioeconomics and ecosystem benefits. Maintaining Ecological Balance had the highest performance value followed by preservation, protection and conservation; followed by reduced ecological and carbon footprints; coordination and harmonization of policies; secured physicochemical environment; high circularity; integrated environmental assessment; bioremediation; secured species dynamics; and effective stockpile management. 


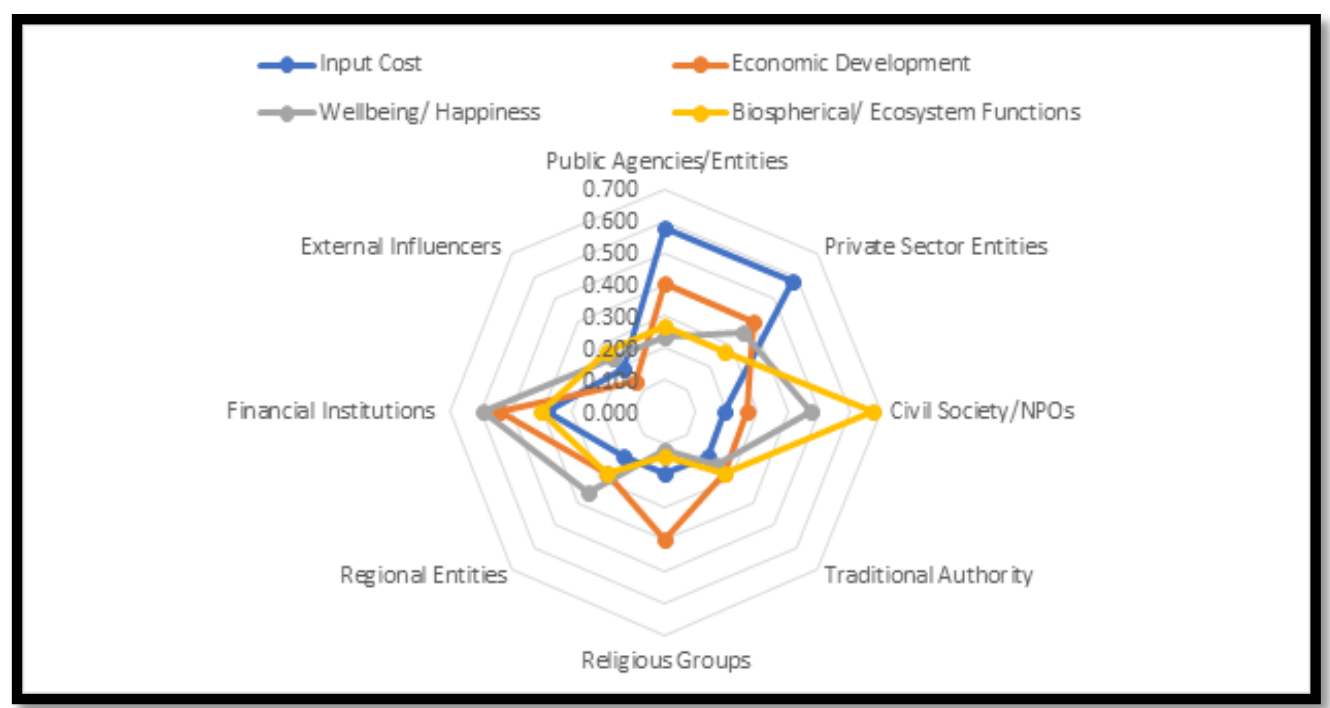

Figure 4: Institutional Radar from Normalized Matrix

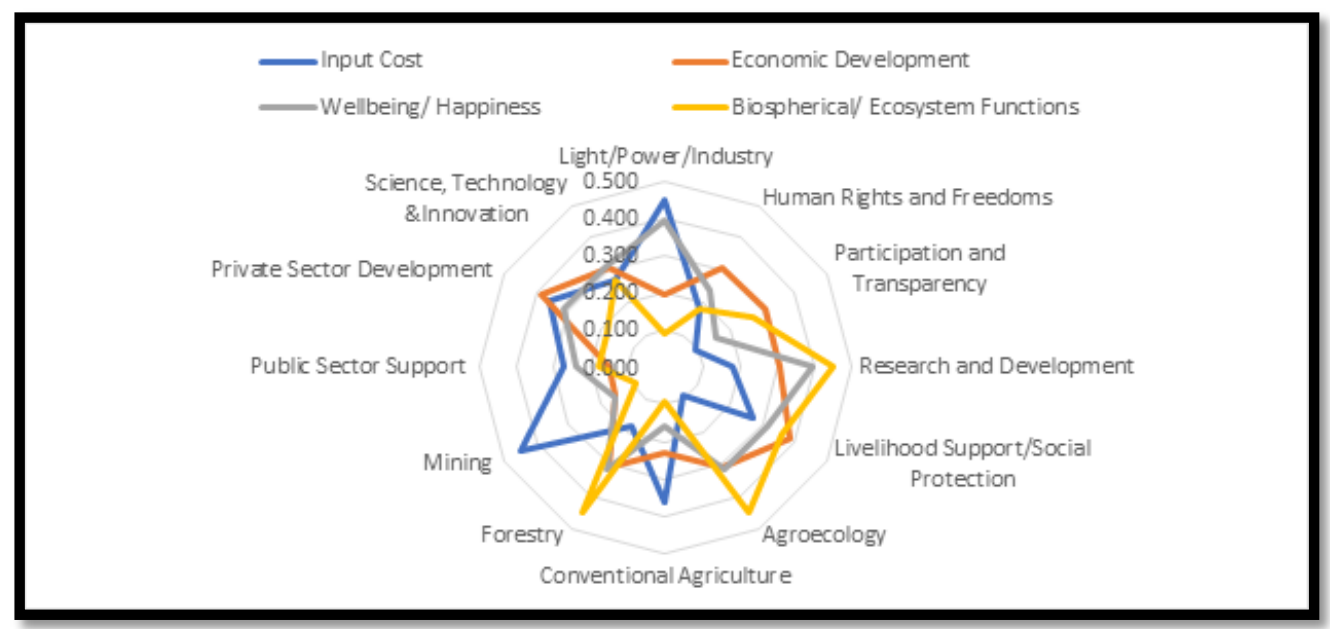

Figure 5: Normalized Developmental Objects

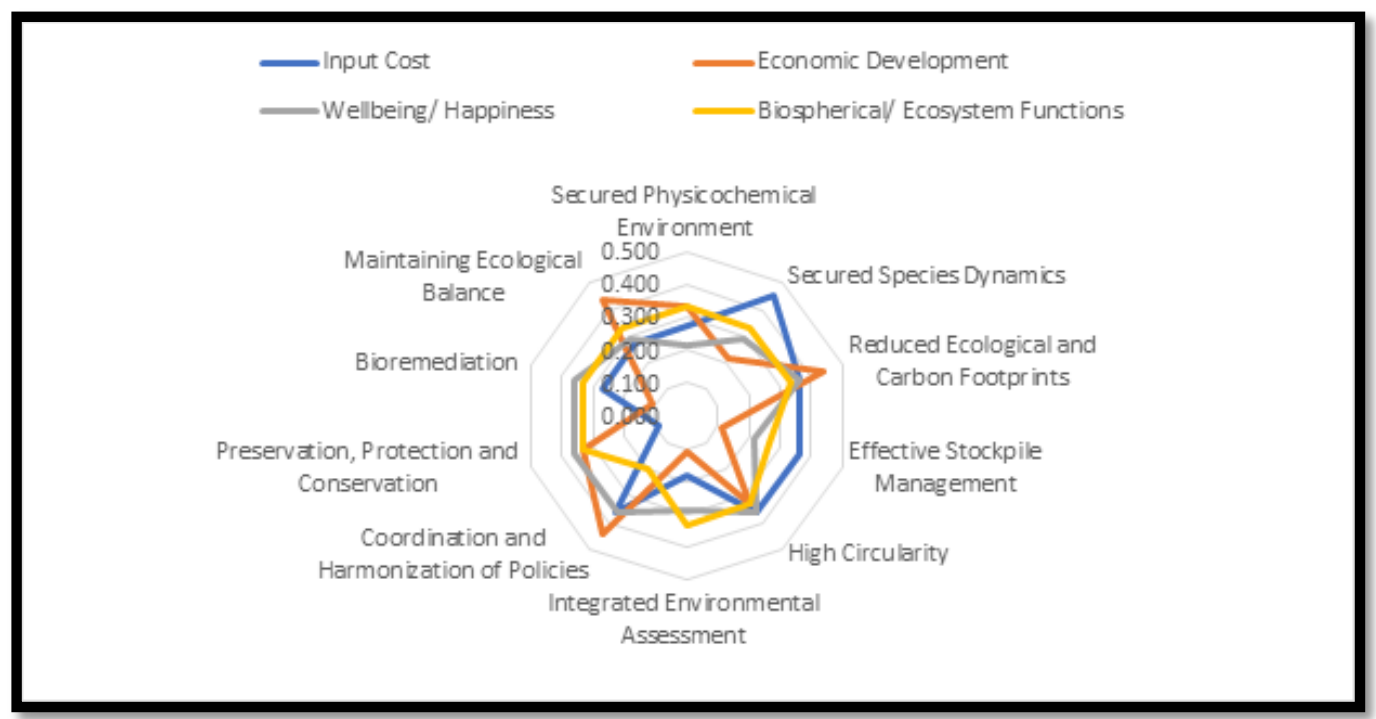

Figure 6: Normalized Environmental Interest 


\begin{tabular}{|c|c|c|c|c|c|c|c|c|}
\hline \multirow{3}{*}{ 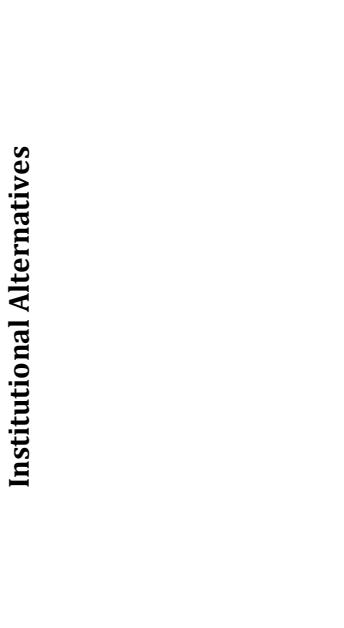 } & $\vec{\Xi}$ & \multicolumn{3}{|l|}{ Dً } & \multicolumn{2}{|l|}{ 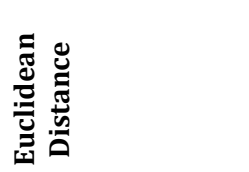 } & \multirow[t]{3}{*}{ 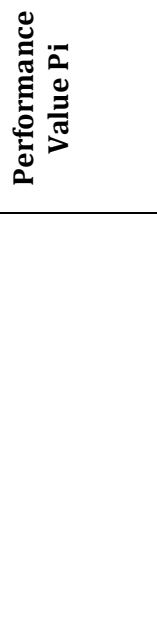 } & \multirow[t]{3}{*}{ 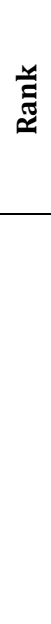 } \\
\hline & $\overrightarrow{\tilde{g}}$ & 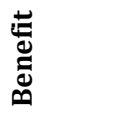 & 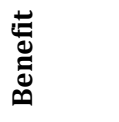 & 苞 & & & & \\
\hline & 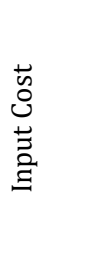 & 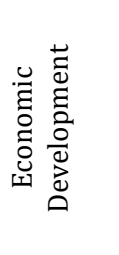 & 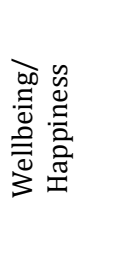 & 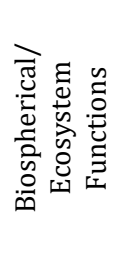 & 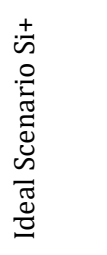 & 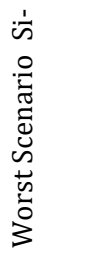 & & \\
\hline Weightage/Importance & 0.2 & 0.25 & 0.25 & 0.3 & & & & \\
\hline Public Agencies/Entities & 0.115 & 0.100 & 0.059 & 0.081 & 0.172 & 0.083 & 0.327 & 7 \\
\hline Private Sector Entities & 0.115 & 0.100 & 0.088 & 0.081 & 0.159 & 0.098 & 0.381 & 5 \\
\hline Civil Society/NPOs & 0.038 & 0.067 & 0.118 & 0.202 & 0.073 & 0.203 & 0.735 & 1 \\
\hline Traditional Authority & 0.038 & 0.067 & 0.059 & 0.081 & 0.164 & 0.098 & 0.373 & 4 \\
\hline Religious Groups & 0.038 & 0.100 & 0.029 & 0.040 & 0.203 & 0.102 & 0.334 & 6 \\
\hline Regional Entities & 0.038 & 0.067 & 0.088 & 0.081 & 0.151 & 0.110 & 0.423 & 3 \\
\hline Financial Institutions & 0.077 & 0.134 & 0.147 & 0.121 & 0.090 & 0.179 & 0.666 & 2 \\
\hline External Influencers & 0.038 & 0.033 & 0.059 & 0.081 & 0.181 & 0.051 & 0.221 & 8 \\
\hline Ideal Best V+ & 0.038 & 0.134 & 0.147 & 0.202 & & & & \\
\hline Ideal Worst V- & 0.115 & 0.033 & 0.029 & 0.040 & & & & \\
\hline
\end{tabular}

Table 1: Institutional Prioritization Matrix

\begin{tabular}{|c|c|c|c|c|c|c|c|c|}
\hline \multirow{3}{*}{$\begin{array}{l}\text { Socioeconomic } \\
\text { Alternatives }\end{array}$} & Input & \multicolumn{3}{|c|}{ Output } & \multicolumn{2}{|c|}{ Euclidean Distance } & \multirow{3}{*}{$\begin{array}{c}\text { Performance } \\
\text { Value Pi }\end{array}$} & \multirow[t]{3}{*}{ Rank } \\
\hline & Cost & Benefit & Benefit & Benefit & & & & \\
\hline & $\begin{array}{l}\dot{n} \\
0 \\
\dot{y} \\
\vdots \\
\vdots \\
\Xi\end{array}$ & 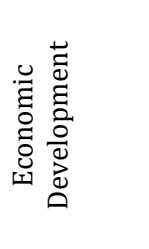 & 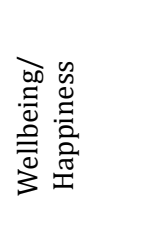 & 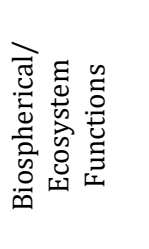 & 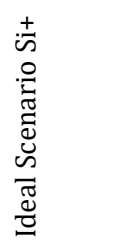 & 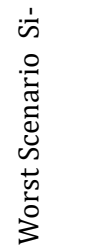 & & \\
\hline $\begin{array}{l}\text { Weightage } \\
\text { /Importance }\end{array}$ & 0.2 & 0.25 & 0.25 & 0.3 & & & & \\
\hline $\begin{array}{l}\text { Light/Power } \\
\text { /Industry }\end{array}$ & 0.090 & 0.048 & 0.099 & 0.027 & 0.138 & 0.118 & 0.460 & 9 \\
\hline $\begin{array}{l}\text { Human Rights and } \\
\text { Freedoms }\end{array}$ & 0.036 & 0.077 & 0.059 & 0.054 & 0.094 & 0.107 & 0.532 & 6 \\
\hline $\begin{array}{l}\text { Participation and } \\
\text { Transparency }\end{array}$ & 0.018 & 0.077 & 0.040 & 0.081 & 0.082 & 0.110 & 0.571 & 5 \\
\hline $\begin{array}{l}\text { Research and } \\
\text { Development }\end{array}$ & 0.036 & 0.077 & 0.099 & 0.135 & 0.026 & 0.057 & 0.685 & 3 \\
\hline $\begin{array}{l}\text { Livelihood } \\
\text { Support/Social } \\
\text { Protection }\end{array}$ & 0.054 & 0.096 & 0.079 & 0.108 & 0.049 & 0.049 & 0.500 & 7 \\
\hline Agroecology & 0.018 & 0.077 & 0.079 & 0.135 & 0.028 & 0.077 & 0.737 & 1 \\
\hline $\begin{array}{l}\text { Conventional } \\
\text { Agriculture }\end{array}$ & 0.072 & 0.058 & 0.040 & 0.027 & 0.140 & 0.130 & 0.482 & 11 \\
\hline Forestry & 0.036 & 0.077 & 0.079 & 0.135 & 0.033 & 0.061 & 0.648 & 4 \\
\hline Mining & 0.090 & 0.038 & 0.040 & 0.027 & 0.154 & 0.136 & 0.469 & 8 \\
\hline $\begin{array}{l}\text { Public Sector } \\
\text { Support }\end{array}$ & 0.054 & 0.038 & 0.059 & 0.054 & 0.113 & 0.113 & 0.500 & 7 \\
\hline $\begin{array}{l}\text { Private Sector } \\
\text { Development }\end{array}$ & 0.072 & 0.096 & 0.079 & 0.054 & 0.099 & 0.085 & 0.462 & 10 \\
\hline $\begin{array}{c}\text { Science, } \\
\text { Technology } \\
\text { \&Innovation }\end{array}$ & 0.054 & 0.077 & 0.079 & 0.081 & 0.030 & 0.070 & 0.704 & 2 \\
\hline Ideal Best V+ & 0.018 & 0.096 & 0.099 & 0.135 & & & & \\
\hline Ideal Worst V- & 0.090 & 0.096 & 0.099 & 0.135 & & & & \\
\hline
\end{tabular}




\begin{tabular}{|c|c|c|c|c|c|c|c|c|}
\hline \multirow{3}{*}{$\begin{array}{l}\text { Environmental } \\
\text { Alternatives }\end{array}$} & \multirow{3}{*}{$\begin{array}{c}\text { Input } \\
\text { Cost } \\
\text { Input } \\
\text { Cost }\end{array}$} & \multicolumn{3}{|c|}{ Output } & \multirow{2}{*}{\multicolumn{2}{|c|}{ Euclidean Distance }} & \multirow{3}{*}{$\begin{array}{c}\text { Performance } \\
\text { Value Pi }\end{array}$} & \multirow[t]{3}{*}{ Rank } \\
\hline & & \multirow{2}{*}{$\begin{array}{c}\text { Benefit } \\
\text { Economic } \\
\text { Development }\end{array}$} & \multirow{2}{*}{$\begin{array}{c}\text { Benefit } \\
\text { Wellbeing/ } \\
\text { Happiness }\end{array}$} & \multirow{2}{*}{$\begin{array}{c}\text { Benefit } \\
\text { Biospherical/ } \\
\text { Ecosystem } \\
\text { Functions }\end{array}$} & & & & \\
\hline & & & & & $\begin{array}{c}\text { Ideal } \\
\text { Scenario } \\
\text { Si+ } \\
\end{array}$ & $\begin{array}{c}\text { Worst } \\
\text { Scenario } \\
\text { Si- } \\
\end{array}$ & & \\
\hline $\begin{array}{c}\text { Weightage } \\
\text { /Importance }\end{array}$ & 0.2 & 0.25 & 0.25 & 0.3 & & & & \\
\hline $\begin{array}{c}\text { Secured } \\
\text { Physicochemical } \\
\text { Environment }\end{array}$ & 0.055 & 0.083 & 0.054 & 0.100 & 0.058 & 0.077 & 0.570 & 5 \\
\hline $\begin{array}{c}\text { Secured Species } \\
\text { Dynamics }\end{array}$ & 0.091 & 0.055 & 0.072 & 0.100 & 0.093 & 0.052 & 0.358 & 9 \\
\hline $\begin{array}{c}\text { Reduced Ecological } \\
\text { and Carbon } \\
\text { Footprints } \\
\end{array}$ & 0.073 & 0.110 & 0.090 & 0.100 & 0.055 & 0.100 & 0.648 & 3 \\
\hline $\begin{array}{l}\text { Effective Stockpile } \\
\text { Management }\end{array}$ & 0.073 & 0.028 & 0.054 & 0.080 & 0.107 & 0.027 & 0.201 & 9 \\
\hline High Circularity & 0.073 & 0.083 & 0.090 & 0.100 & 0.061 & 0.079 & 0.565 & 6 \\
\hline $\begin{array}{c}\text { Integrated } \\
\text { Environmental } \\
\text { Assessment } \\
\end{array}$ & 0.036 & 0.028 & 0.072 & 0.100 & 0.087 & 0.070 & 0.447 & 7 \\
\hline $\begin{array}{l}\text { Coordination and } \\
\text { Harmonization of } \\
\text { Policies }\end{array}$ & 0.073 & 0.110 & 0.090 & 0.060 & 0.068 & 0.092 & 0.577 & 4 \\
\hline $\begin{array}{l}\text { Preservation, } \\
\text { Protection and } \\
\text { Conservation }\end{array}$ & 0.018 & 0.083 & 0.090 & 0.100 & 0.028 & 0.106 & 0.793 & 2 \\
\hline Bioremediation & 0.055 & 0.028 & 0.090 & 0.100 & 0.090 & 0.065 & 0.418 & 8 \\
\hline $\begin{array}{c}\text { Maintaining } \\
\text { Ecological Balance } \\
\end{array}$ & 0.055 & 0.110 & 0.072 & 0.100 & 0.041 & 0.174 & 0.811 & 1 \\
\hline Ideal Best V+ & 0.018 & 0.110 & 0.090 & 0.100 & & & & \\
\hline Ideal Worst V- & 0.091 & 0.028 & 0.054 & 0.060 & & & & \\
\hline
\end{tabular}

\section{Table 3: Prioritization Matrix for Biospherical Pivot}

From the figures (Figure 4, 5 and 6) and tables (Tables 1, 2 and 3), it is shown that decision-makers can achieve value for money and accelerate the achievement of sustainable development, wellbeing and environmental goals by adopting and scaling up the priorities emanating from BAR-X framework. As shown for institutional prioritization Schoeberlein (2020) and Tritto (2019) argue that civil society, financial institutions and independent media play an increasingly important role in Africa's multi-party governance arrangements. Similarly, while Romano et al. (2020) argue for agroecology as being historically promising and outstanding for socioeconomic and environmental benefits Surana et al. (2020) contend that science, technology and innovation in developing economies promote entrepreneurship and support start-ups to grow from incubation hubs to successful businesses which can enhance socioeconomic and ecosystem performance. Additionally, under the biospherical pivot Verma (2019) argues that ensuring ecological balance is the only means of progressing from unsustainable to sustainable development and that if there is an opportunity to invest the proceeds of extractive resources it should be to maintain ecological balance as it promises inter- and intra-generational equity.

\section{Conclusion and Recommendations}

The review and analyses have demonstrated that extractive resource governance arrangements can guarantee sustainability by strengthening linkages and interrelationships between and among institutions, developmental mandates and the components of the biosphere. Ensuring policy coherence of the 10 Barrow indices can be promising for institutional, developmental and ecosystem productivity, intergenerational equity, human security and social wellbeing. Formal and informal institutions, civil society and religious institutions can play their regulatory, advocacy and stewardship roles to ensure that wellbeing, security, and intergenerational needs of resource-rich economies and communities are addressed by local policies, popular participation and rights-based benefit-sharing arrangements. It is shown that African governments and governance actors in extractive resources must improve on transparency and participation in the operations of development institutions. The media, civil society and communities must monitor the performance of institutions and protest strongly if positive results are to be obtained on financial, developmental, environmental, and corporate citizenship. Development institutions must conduct regular public surveys of citizens, stakeholders, and communities to rate their commitment to the developmental mandate from the use of proceeds of minerals and other natural resources. The Barrow Framework offers a critical lens to examine policy needs and stakeholder commitment towards ensuring the principles of sustainability are upheld at all levels of governance and in implementation strategies. Under limited resource conditions, it is recommended to prioritize civil society organisations, financial institutions and regional entities to drive developments in agroecology, science technology and innovations and to further promote ecological balance, preservation, protection and conservation. 


\section{Acknowledgements}

The authors are thankful for the sponsorship provided by Agency for Health and Food Security (AHEFS) to make this study a reality. The assistance provided by SDG Africa Independent Assessors (SDGAIA), researchers and stakeholders who made their requested works available for this study are also appreciated.

\section{References}

i. Adams, D., Ullah, S., P., A., Adams, K., \& Saidi, S. (2018). The Role of Country-level Institutional Factors in Escaping the Natural Resource Curse: Insights from Ghana. Resource Policy, 0-33.

ii. Adewuyi, A. O., \& Olubiyi, E. (2020). Do Governance Institutions Matter for Trade Flows between Sub-Saharan Africa and its Trading Partners?

iii. Africa Union. (2009). Africa Mining Vision. Development, February, 1-51. http://www.africaminingvision.org/amv_resources/AMV/Africa_Mining_Vision_English.pdf

iv. Agelebe, D. O. (2019). Integrating Liberal Economic Regulation with Environmental Protection: Ethiopia, Zambia, Mali and Ghana. Australasian Review of African Studies, 40(1), 1-126.

v. Ahiakpor, J. C. W. (1985). The success and failure of dependency theory: the experience of Ghana. International Organization, 39(3), 535-552. https://doi.org/10.1017/s0020818300019172

vi. Aina, K. (2018). Advancing Towards a More Effective Stakeholder Engagement by Multinational Companies in Nigeria *. IOSR Journal of Business and Management (IOSR-JBM), 20(6), 20-34. https://doi.org/10.9790/487X2006072034

vii. Akana, A. O., \& Ikegbunam, F. I. (2019). Natural Resource Exploitation in Nigeria: Consequences of Human Actions and Best Practices for Environmental Sustainability-A Review. Sparkling International Journal of Multidisciplinary Research Studies, 2(3), 1-14.

viii. Alozie, A. C. (2019). Sustainable management of Mineral Resource Active Regions : A Participatory Framework for the Application of Systems Thinking Alaoma Chidirim Alozie (Issue May).

ix. Alumona, I. M., \& Onwuanabile, K. (2019). Environmental Insecurity in Nigeria. In Internal Security Management in Nigeria (Issue July). https://doi.org/10.1007/978-981-13-8215-4

x. Ambe-Uva, T. (2017). Whither the state? Mining codes and mineral resource governance in Africa. Canadian Journal of African Studies, 51(1), 81-101. https://doi.org/10.1080/00083968.2016.1277148

xi. Anand, B. (2013). Sustainability and the Capability Approach : Capability Approach and Sustainability: From Theory to Practice? Chapter Forthcoming in Ibrahim S and Tiwary M(Ed) Capability Approach-from Theory to Practice, London: Palgrave, 1-27.

xii. Andrews, N., \& Okpanachi, E. (2020). Depoliticisation and a historicism of transparency and accountability via global norms: assessing the EITI in Ghana and Nigeria. Commonwealth and Comparative Politics, 58(2), 228-249. https://doi.org/10.1080/14662043.2020.1735088

xiii. Ango, M., Erdenebat, B., \& Tang, K. Y. (2019). Creation of a Sustainable Mining Program through Formalization of Artisanal and Small Scale Miners. Columbia University, May, 88.

xiv. Ballet, J., Bazin, D., Dubois, J. L., \& Mahieu, F. R. (2011). A note on sustainability economics and the capability approach. Ecological Economics, 70(11), 1831-1834. https://doi.org/10.1016/j.ecolecon.2011.05.009

xv. Barreto, M. L., Schein, P., Hinton, J., \& Hruschka, F. (2018). The Impact of Small-Scale Mining Operations on Economies and Livelihoods in Low- to Middle-Income Countries (Issue January).

xvi. Bauer, A., Gankhuyag, U., Halling, S., Manley, D., \& Venugopal, V. (2016). Natural Resource Revenue Sharing. In Newspaper (Issue September). https://doi.org/10.1177/0921810697103012

xvii. Bentham, J., Singh, G. M., Danaei, G., Green, R., Lin, J. K., Stevens, G. A., Farzadfar, F., Bennett, J. E., Di Cesare, M., Dangour, A. D., \& Ezzati, M. (2020). Multidimensional characterization of global food supply from 1961 to 2013. Nature Food, 1(1), 70-75. https://doi.org/10.1038/s43016-019-0012-2

xviii. Besada, H., \& Martin, P. (2015). Mining codes in Africa: emergence of a 'fourth' generation? Cambridge Review of International Affairs, 28(2), 263-282. https://doi.org/10.1080/09557571.2013.840823

xix. Boafo, J., Paalo, S. A., \& Dotsey, S. (2019). Illicit Chinese small-scale mining in Ghana: Beyond institutional weakness? Sustainability (Switzerland), 11(21), 1-18. https://doi.org/10.3390/su11215943

xx. Bradly, A., \& Nathan, G. (2019). Institutional CSR: provision of public goods in developing economies. Social Responsibility Journal, 15(7), 874-887. https://doi.org/10.1108/SRJ-01-2018-0019

xxi. Clark, D. A. (2005). Sen's capability approach and the many spaces of human well-being. Journal of Development Studies, 41(8), 1339-1368. https://doi.org/10.1080/00220380500186853

xxii. Croitoru, L., Miranda, J. J., Khattabi, A., \& Lee, J. J. (2020). The Cost of Coastal Zone Degradation in Nigeria. The Cost of Coastal Zone Degradation in Nigeria, October. https://doi.org/10.1596/34758

xxiii. Dabachi, U. M., Mahmood, S., Ahmad, A. U., Ismail, S., Farouq, I. S., Jakada, A. H., Mustapha, U. A., Abdullahi, A. T., Muhammad, A. A., \& Kabiru, K. (2020). Energy consumption, energy price, energy intensity environmental degradation, and economic growth nexus in African OPEC countries: Evidence from simultaneous equations models. Journal of Environmental Treatment Techniques, 8(1), 403-409.

xxiv. Daum, T., Adu-baffour, F., Daum, T., \& Birner, R. (2020). Governance challenges of small-scale gold mining in Ghana: Insights from a process net-map study. Hohenheim Working Papers on Social and Institutional Change in Agricultural Development, 004-2020(September), 35. 
xxv. Dawson, M., \& Maricut-Akbik, A. (2020). Procedural vs substantive accountability in EMU governance: between payoffs and trade-offs. Journal of European Public Policy, 0(0), 1-20. https://doi.org/10.1080/13501763.2020.1797145

xxvi. Efobi, U., Belmondo, T., Orkoh, E., Atata, S. N., Akinyemi, O., \& Beecroft, I. (2018). Environmental pollution policy of small businesses in Nigeria and Ghana: Extent and impact. African Governance and Development Institute, $\mathrm{WP} / 18 / 050,35$.

xxvii. Fischer, C. (2019). Avoiding Malthus 2.0: Why Food Pessimism Leads Nowhere. American Journal of Biomedical Science \& Research, 6(1), 64-65. https://doi.org/10.34297/ajbsr.2019.06.000993

xxviii. Fuso Nerini, F., Sovacool, B., Hughes, N., Cozzi, L., Cosgrave, E., Howells, M., Tavoni, M., Tomei, J., Zerriffi, H., \& Milligan, B. (2019). Connecting climate action with other Sustainable Development Goals. Nature Sustainability, 2(8), 674-680. https://doi.org/10.1038/s41893-019-0334-y

xxix. Giurco, D., Evans, G., Cooper, C., Mason, L., \& Franks, D. (2009). Mineral Futures Discussion Paper: Sustainability Issues, Challenges and Opportunities. 1-71.

xxx. Hashemi, A., Dowlatshahi, M. B., \& Nezamabadi-pour, H. (2020). MFS-MCDM: Multi-label feature selection using multi-criteria decision making. Knowledge-Based Systems, 206, 106365. https://doi.org/10.1016/j.knosys.2020.106365

xxxi. Heikkila, T., \& Andersson, K. (2018). Policy design and the added-value of the institutional analysis development framework. Policy and Politics, 46(2), 309-324. https://doi.org/10.1332/030557318X15230060131727

xxxii. Henckens, M. L. C. M., Biermann, F. H. B., \& Driessen, P. P. J. (2019). Mineral resources governance: A call for the establishment of an International Competence Center on Mineral Resources Management. Resources, Conservation and Recycling, 141(May 2018), 255-263. https://doi.org/10.1016/j.resconrec.2018.10.033

xxxiii. Idemudia, U., Kwakyewah, C., \& Muthuri, J. (2020). Mining, the environment, and human rights in Ghana: An area of limited statehood perspective. Business Strategy and the Environment, September 2019, 1-8. https://doi.org/10.1002/bse.2581

xxxiv. Igrioglu, G., Ostry, A., \& Allam, M. (2020). Integrated Governance for Coherent Implementation of the SDGs in Egypt. OECD Working Papers on Public Governance, 35(10), 1-46.

xxxv. Krauss, J. (2018). Review of Doughnut Economics: 7 Ways to Think Like a 21st Century Economist by Kate Raworth. Journal of World-Systems Research, 24(2), 452-457. https://doi.org/10.5195/jwsr.2018.854

xxxvi. Kuan, S. H., Ghorbani, Y., \& Chieng, S. (2020). Narrowing the gap between local standards and global best practices in bauxite mining: A case study in Malaysia. Resources Policy, 66(October 2019), 101636. https://doi.org/10.1016/j.resourpol.2020.101636

xxxvii. Li, X., Du, J., \& Long, H. (2019). Theoretical framework and formation mechanism of the green development system model in China. Environmental Development, 32(January), 100465.

https://doi.org/10.1016/j.envdev.2019.100465

xxxviii. Manero, A., Kragt, M., Standish, R., Miller, B., Jasper, D., Boggs, G., \& Young, R. (2020). A framework for developing completion criteria for mine closure and rehabilitation. Journal of Environmental Management, 273(February), 111078. https://doi.org/10.1016/j.jenvman.2020.111078

xxxix. McGinnis, M. D. (2011). An Introduction to IAD and the Language of the Ostrom Workshop: A Simple Guide to a Complex Framework. Policy Studies Journal, 39(1), 169-183. https://doi.org/10.1111/j.1541-0072.2010.00401.x

xl. Meer, B. B., Dishan, E. E., Ikima, D., \& Ateh, G. O. (2020). Ecological implications of environmental contaminants on biodiversity and ecosystem services : The Nigerian Experience. Basic Research Journal of Soil and Environmental Science, 2(June), 1-10.

xli. Melo, F. P. L., Parry, L., Brancalion, P. H. S., Pinto, S. R. R., Freitas, J., Manhães, A. P., Meli, P., Ganade, G., \& Chazdo n, R. L. (2020). Adding forests to the water-energy-food nexus. Nature Sustainability, 10(September), 1-9. https://doi.org/10.1038/s41893-020-00608-z

xlii. Mensah, A. K., Mahiri, I. O., Owusu, O., Mireku, O. D., Wireko, I., \& Kissi, E. A. (2015). Environmental Impacts of Mining : A Study of Mining Communities in Ghana. Applied Ecology and Environmental Sciences, 3(3), 81-94. https://doi.org/10.12691/aees-3-3-3

xliii. Mezeli, M. M., Page, S., George, T. S., Neilson, R., Mead, A., Blackwell, M. S. A., \& Haygarth, P. M. (2020). Using a meta-analysis approach to understand complexity in soil biodiversity and phosphorus acquisition in plants. Soil Biology and Biochemistry, 142(December), 107695. https://doi.org/10.1016/j.soilbio.2019.107695

xliv. Mutize, M., \& Tefera, E. (2020). The Governance of State-Owned Enterprises in Africa: An Analysis of Selected Cases. Journal of Economics and Behavioral Studies, 21(1), 1-9. https://doi.org/10.1155/2010/706872

xlv. Natural Resource Governance Institute. (2015). Subnational Revenue Distribution: Natural Resource Revenues in a Decentralized Context (Issue March).

xlvi. Ngan, S. L., How, B. S., Teng, S. Y., Promentilla, M. A. B., Yatim, P., Er, A. C., \& Lam, H. L. (2019). Prioritization of sustainability indicators for promoting the circular economy: The case of developing countries. Renewable and Sustainable Energy Reviews, 111, 314-331. https://doi.org/10.1016/j.rser.2019.05.001

xlvii. Obiri, K. A., \& Bjeirmi, B. (2019). A Comparative Analysis of Local Content Policies in the North Sea and the Gulf of Guinea Regions. Journal of Scientific Research and Reports, 25(5), 1-13. https://doi.org/10.9734/jsrr/2019/v25i530195

xlviii. Ojakorotu, V. (2019). Ubuntu and Nature: Towards Reversing Resource Curse in Africa. Ubuntu: Journal of Conflict and Social Transformation, 8(2), 25-46. https://doi.org/10.31920/2050-4950/2019/sin2a2 
xlix. Ostrom, E. (2009). "Governing the Commons" The Evolution of Institutions for Collective Action. Cambridge University, New York, July.

l. Pislaru, M., Herghiligiu, I. V., \& Robu, I. B. (2019). Corporate sustainable performance assessment based on fuzzy logic. Journal of Cleaner Production, 223, 998-1013. https://doi.org/10.1016/j.jclepro.2019.03.130

li. Prpich, G., Sam, K., \& Coulon, F. (2019). Stakeholder Engagement and Sustainable Environmental Management of oil contaminated sites in Nigeria. Energy in Africa: Policy, Management and Sustainability, 319(3), 1-31.

lii. Rauschmayer, F., \& Leßmann, 0. (2011). Assets and drawbacks of the CA as a foundation for sustainability economics. Ecological Economics, 70(11), 1835-1836. https://doi.org/10.1016/j.ecolecon.2011.06.023

liii. Romano, J., Pérez-Chinarro, E., \& Coral, B. V. (2020). Network of Landscapes in the Sustainable Management of Transboundary Biosphere Reserves. Land, 9(9), 320. https://doi.org/10.3390/land9090320

liv. Sarkodie, S. A. (2020). Environmental performance, biocapacity, carbon \& ecological footprint of nations: Drivers, trends and mitigation options. Science of the Total Environment, 751, 141912.

https://doi.org/10.1016/j.scitotenv.2020.141912

lv. Schoeberlein, A. J. (2020). National strategies for advancing good governance in Africa. Transparency International Anti-Corruption Helpdesk, 2020, 24.

lvi. Seck, S. L., Majekolagbe, B., Doelle, M., Metallic, N., \& Simons, P. (2020). Impact Assessment and Responsible Business Guidance Tools in the Extractive Sector: Implications for Human Rights, Gender and Stakeholder Engagement. Marine and Environmental Law Institute, 5-29-2020(April), 65.

lvii. Sor, R., Ngor, P. B., Boets, P., Goethals, P. L. M., Lek, S., Hogan, Z. S., \& Park, Y.-S. (2020). Patterns of Mekong Mollusc Biodiversity: Identification of Emerging Threats and Importance to Management and Livelihoods in a Region of Globally Significant Biodiversity and Endemism. Water, 12(9), 2619. https://doi.org/10.3390/w12092619

lviii. Surana, K., Singh, A., \& Sagar, A. (2020). Strengthening science, technology, and innovation-based incubators to help achieve Sustainable Development Goals: Lessons from India. ArXiv, 1-56.

lix. Suryawan, I. G. B., \& Aris, I. (2020). Strengthening environmental law policy and its influence on environmental sustainability performance: empirical studies of green constitution in adopting countries. International Journal of Energy Economics and Policy, 10(2), 132-138. https://doi.org/10.32479/ijeep.8719

lx. Tritto, A. (2019). The Belt and Road Initiative as a catalyst for institutional development. IEMS Policy Brief, 30, 14. https://iems.ust.hk/publications/thought-leadership-briefs/tritto-belt-and-road-initiative-institutionaldevelopment-tlb30

lxi. Twerefou, D. K. (2009). Mineral Exploitaiton, Environmental Sustainability and Sustainable Development in EAC, SADC and ECOWAS Regions. Economic Commision of Africa, 79, 55.

lxii. Verma, A. K. (2019). Sustainable development and environmental values. Socijalna Ekologija, 10(1), 149-162.

lxiii. Willy, D. K., Muyanga, M., Jayne, T., \& Mbuvi, J. (2019). More People Less Erosion? An Evaluation of the Effects of Intensive Agricultural Land Use on Soil Organic Carbon Dynamics in Densely Populated Areas. 6th African Conference of Agricultural Economists, September 23-26, 2019, Abuja, Nigeria, 1-29.

lxiv. Wilson, M. L., Renne, E., Roncoli, C., \& Agyei-baffour, P. (2015). Integrated Assessment of Artisanal and Small-Scale Gold Mining in Ghana - Part 3 : Social Sciences and Economics. International Journal of Environmental Research and Public Health, 8133-8156. https://doi.org/10.3390/ijerph120708133

lxv. World Bank. (2020). Country Environmental Analysis (W. B. Group (ed.); Issue April). World Bank Publications.

lxvi. World Commission On Environment And Development. (1987). Our Common Future. Wced, 17, 1-91.

lxvii. Zilberman, D., Goetz, R., Garrido, A., \& Ayuk, E. (2019). New Frontiers in Natural Resources Management in Africa (Vol. 53, Issue July). https://doi.org/10.1007/978-3-030-11857-0 